tion is similar to that reported by Rogers" when a deer was seen playing with Sharp-tailed Grouse in Colorado, striking at them with head and feet. These grouse merely moved a short distance and resumed dancing.

Sharp-tailed Grouse, when absorbed in the dance, are easy prey to coyotes according to Bent ${ }^{3}$. Rogers ${ }^{2}$ says that few things distract dancing Sharptailed Grouse. He reports six ravens, four ducks and two hawks spending an entire morning watching dancing grouse in Colorado. The hawks occasionally disrupted activity by swooping at the birds. When a coyote watched dancing sharp-tails, the grouse paid little attention to the intruder.

Predation on dancing Sharp-tailed Grouse is noted most years by DNR personnel. Wayne Pepper' has found remains of five banded and other unbanded grouse, apparently killed by predators, all within 300 yards of dancing grounds near Asquith. This is supporting evidence that predation at dancing grounds is not uncommon.

I wish to thank Wayne Pepper and Dr. C. Stuart Houston for their help with this article.

'BENT, E. C. 1963. Life histories of North American gallinaceous hirds. Dover Publications Inc., N.Y.

"PEPPER, G. W. 1972. The ecology of Sharp-tailed Grouse during spring and surnmer in the aspen parklands of Saskatchewan. Saskatchewan Dept. Nat. Res. Wildl. Rep. No. 1, 55 pp.

"ROGERS, G. E. 1967. The Sharp-tailed Grouse in Colorado. Colorado Dept. Nat. Res. Tech. Pub. 23, $94 \mathrm{pp}$.

\section{PINE SISKINS NESTING AT MOOSE JAW}

\section{by EDITH KERN*}

Bird-watchers of the Moose Jaw Natural History Society were quite excited to have found two known Pine Siskin nests in the city in the spring of 1973. One nest, well hidden, was

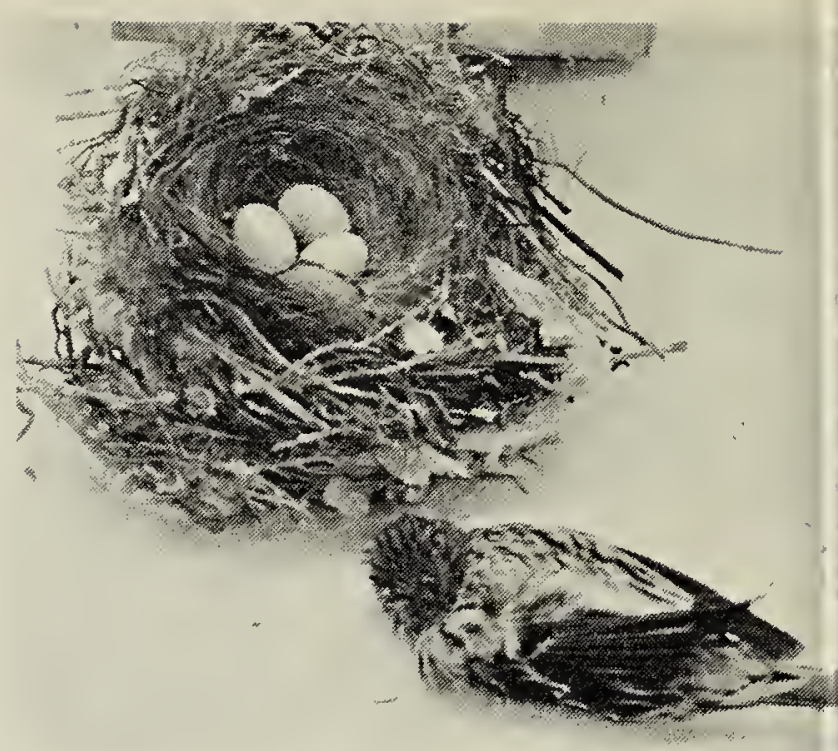

Pine Siskin and nest. Regina Leader-Po

found about 5 or 6 feet up in a spru tree at the Ken Bidwell home near th centre of the city. The Bidwell fami had seen the birds around for 2 or weeks in March and, after realizir they were probably nesting, kept clos watch for about 10 days. On April they decided that the nest had be deserted, and on April 6 removed tl nest which had three eggs in it. $c$ April 7 they found the dead fema Pine Siskin. They then informe Leith Knight, president of MJNH who suggested that the nest and skin turned over to the Saskatchew: Museum of Natural History. Fre Lahrman has since informed us th the eggs were "very heavily i cubated."

The second nest was in a taller tre several blocks northwest of the fii nest-site, and was active until abo May 2, when all activity ceased an the birds disappeared. Cats a thought to be the cause. The nest $w$ too high up to be retrieved.

As of May 12 there were numero flocks of 8 to 15 Pine Siskins coming daily to feeders (sunflower seed) other areas of the city but no oth nests were discovered. Also, Eveni Grosbeaks (adult male and femal and immature Red Crossbills (ma and female) were still coming in da to feeders (sunflower seed) in seves areas of the city.

*1086 Alder Ave.,

Moose Jaw, Saskatchewan.

S6H OY 4 